\title{
The Scale Effect of Investments and Tax Incomes intended to Public Sector Borrowing Requirement in Last Period: Turkish Case
}

\author{
Ahmet Niyazi Özker \\ Orcid ID: 0000-0001-5313-246X \\ Faculty of Economic and Business Administration, \\ Bandirma Onyedi Eylul University - TURKEY
}

\begin{abstract}
In this study, we attempt to put forth the structural dynamics in which the recent changes in the Public Sector Borrowing Requirement, which is an important phenomenon of the public sector, are related. We consider important that the public sector financial balances are affected by many sub-dynamics considering it is important to better understand the impact level of total investment expenditures and tax revenues in the process of changes in the Public Sector Borrowing Requirement (PSBR). However, it is also meaningful to question the changes in the borrowing requirement in the other macro dynamics that constitute the effect level in the process. Therefore, values such as percentage changes in export limits, consumer confidence index and consumption investments in foreign markets were also included in our study. In this study, it was tried to determine the scale effect of the findings within the framework of an econometric model and the results were found to be meaningful as a result of the current interpretation from a financial economics perspective.
\end{abstract}

Key Words: Financial Balances, Macro Dynamics, Public Sector Borrowing Requirement (PSBR), Tax Income.

JEL Codes: H23, H30, H63.

\section{INTRODUCTION}

The Public Sector Borrowing Requirement has an important place in terms of achieving financial balances in the recent public expenditures and formulating the fiscal policies related to the process. In particular questioning the growing public debt and structural internal dynamics in Turkey and the value of determining the contribution level with other macro variables, it is important in terms of being transformed into a selective nature of fiscal policy. The Public Sector Borrowing Requirement (PSBR) has a significant financial equilibrium feature, especially for developing countries, because of its impact on these macro variables (Yeldan, 1997). The main components of the PSBR can be expressed as Consolidated Budget Deficit, Local Government Deficit, Fund Deficits and Financial Deficits related to Social Security Institutions. The striking feature of the PBSR as a phenomenon is that, in terms of public financial balance, this phenomenon expresses a greater public finance balance than the operational deficit and primary deficit concepts (Blejer and Cheasty, 1991). In this respect, the PSBR refers to the balances of the public sector as well as the financing of possible public deficits through borrowing and emission at the present days. However, the alteration rates for PSBR as a percent rate in the priority value is more significant than its current constant values with the ratio of these values to Gross National Product (GNP).

One of the main studies on the subject related to Turkey that made by The Central Bank of the Republic of Turkey in 2002 as an analytical study has been taken an important place. In this study, as the dynamic financial features related to the public finance, particularly in Turkey, we 
see put forth the public financial payments in terms of detection of significant relationship between balance and tax revenues (Aras and Öztürk, 2011). Another of the important work carried out in Turkey in recent years for the Public Sector Borrowing Requirement (PSBR) concept, it is his work of Arslan and the others (Arslan et al., 2019). The study dealt with the changes, as connected with the budget balances in recent years in Turkey, this study dealt specifically financial phenomenon dynamics PSBR has emphasized on the potential financial crisis. Another striking study that emphasizes the effect of monetary balances and monetization phenomenon, especially in terms of PSBR, is the study conducted by Dağ and Tügen (2018). In the study, we observe that the monetary balance dynamics, especially regarding the public financing, has been brought to the fore.

It should not be ignored that the most important revenue component of the Consolidated Budget is tax revenues and there is a significant correlation together, as depends on the structural relations, between PSBR and tax collection. In this context, it should be stated that the ratio of PSBR to GNP should be optimally 3-4 percent and this ratio is determined as 3 percent according to Maastricht criteria (Bank for International Settlement, 2003). If this current ratio is higher than this considered rate, it means that the relevant country enters into a Financial Crowding process that distorts the financial market balances and creates the ground for a possible inflationary process to begin (Alani, 2006). It can be said that if this current ratio is higher than this considered rate, it means that the relevant country enters into a Financial Crowding-Out process that distorts the financial market balances and creates the ground for a possible inflationary process to begin (Central Bank of Republic of Turkey, 2010).

\section{THE STRUCTURAL NATURE OF PUBLIC SECTOR BORROWING REQUIREMENT (PSBR), AND ITS FINANCIAL PROCESS RELATIONSHIP}

The most important feature of the PSBR phenomenon is also financed by emission this relevant value in the relevant public deficits process. This phenomenon, which is expressed as borrowing of the public sector, is financed by printing more money than borrowing. This phenomenon, which is being financed by developing countries by printing more money, also expresses the problem of equilibrium regarding the preferences between emission and borrowing for these countries (Bailey 1995). On the other hand, it is observed to come on the scene that private sector investments have two important contradictions of preference as related to macro balances in countries with the ratio of PSBR to GDP. The first of these contradictions is the exclusion of medium and long-term investments due to the high interest rates in the related process (Keho, 2010). The second is the decline in public savings along with the declining investment tendency, but the increase in short-term speculative market earnings (Wigley et al., 2019).

\section{The Location of Public Sector Cash Balance in The PSBR Process}

The public sector cash deficit process reveals the main current value factors in the calculation of the Public Sector Borrowing Requirement (PSBR). This current cash values approach expresses only the cash value requirement for the relevant year, apart from the periodic structure of the PSBR process (Ucal and Alici, 2010). These cash values are determined as the cash equivalent of the difference between all public revenues and expenses for the year. In other words, it can be said that this approach was put forward to overcome the difficulties in net value determination in PSBR phenomenon. It should be emphasized about the relevant process that PSBR was born according to the cash needs. 
Two different levels of differential effects can be mentioned for this stated phenomenon for investments and tax revenues in the relevant process. The first is the level of influence PSBR exerts in the process, in terms of public investments and especially public economic enterprises. However, the problem here is to update and clarify the cash requirement by the beginning of the year and by the end of the year. In terms of the consolidated budget, the problem relates to the determination of the net figure in the issuance of transfers to these units at the end of the year (OECD, 2018).

The second concerns the determination of the differential effect of tax revenues in the calculation of PSBR. Indeed, revealing the scale effects of tax revenues for the year poses important problems in determining the net value of PSBR (World Bank, 2013). Although it is possible to recognize the cash values given in advance or the financial values that are entrusted as cash deficits, it would be able to cause years of financial problems in the net reveal of PSBR values periodically. In this context, the fact that the state frequently enters the capital market for PSBR and creates a significant debt demand in the markets causes other important market imbalances. In other words, public borrowing demand and increasing market interest rates and emission volumes lead to further increase in PSBR deficits and push financial public balances into an even worse financing balance process (Gürkaynak et al., 2015). At this stage, it is important to note that the revolving fund accounts are not included in the PSBR accounts in the relevant process, since the revolving fund accounts have a very low proportional value for the PSBR. But at this stage, it should be emphasized that the primary deficit effect for the PSBR stems from the deficits arising from the Consolidated Budget (Nikoloski and Nedonovski, 2017).

\section{The Last Term Real Variability of PSBR and its Distributional Location in the GDP}

Public Sector Borrowing Requirement (PSBR) has a structural position that constitutes a significant financial and economic influence in Turkey. In this respect, PSBR has an important place especially in the interpretation of budget deficits and understanding of possible cash deficits. Regardless of this perspective, PSBR should be a subject to interpretation and evaluation toward GDP due to put forth the meaningful fiscal and economics trend. The financial fragility, especially in countries such as Turkey is very high meaningful comments must be dealt with cyclical macro variables covering the entire period (Ünver and Doğru, 2015). In a process where current values are highly fluctuated and primary budget values are considered and evaluated, changes in PSBR values have put forth a more meaningful structure to analyse the periodical fiscal balances (Ertuğrul and Selçuk, 2002).

In the context, after 2010 it is seen that the PSB has experienced a fluctuating trend change values in Turkey. There may be mentioned two reasons for this financial turbulence in Turkey. One of these reasons is that PSBR values increased in real terms during periods of global financial crises such as 2009 crisis. Indeed, the 2009 budget deficit in Turkey and payments balances in developing countries and in the deficit in financial balances caused the significant financial losses (Iyidogan, 2013). The second leading cause of financial volatility associated with the event is the loss due to the negative unsuitable fiscal adjustment process in Turkey arising from the structural policies in the period after 2009, especially the financial crisis. In Table 1 below, it is possible to see the trend of change and undulation in the current values on GDP and PSBR basis.

As observed in Table 1, while GDP has been in the constant current value increase, PSBR as a current value has been in the fluctuating changeably process, and directly affects public cash deficit. The approach that draws attention in this process is that the ratio of PSBR to GDP has shown a highly variable and fluctuating structure after 2009. In terms of GDP, even if current fiscal values are taken in Table 1 , it has been included in our study as a real value as a 
proportional increase based PSBR in our study. Therefore, the PSBR value as a ratio of GDP is a real proportional value and constitutes the main theme of variability in the process.

Table 1. General View of the Public Sector Borrowing Requirement After 2009

\begin{tabular}{|c|c|c|c|}
\hline Years & GDP (TL) & PSBR (TL) & PSBR / GDP (\%) \\
\hline $\mathbf{2 0 0 9}$ & 999.200 .000 & 48.091 .446 & 4,81 \\
\hline $\mathbf{2 0 1 0}$ & 1.160 .000 .000 & 25.949 .164 & 2,24 \\
\hline $\mathbf{2 0 1 1}$ & 1.394 .500 .000 & 1.790 .493 & 0,13 \\
\hline $\mathbf{2 0 1 2}$ & 1.569 .700 .000 & 13.878 .601 & 0,88 \\
\hline $\mathbf{2 0 1 3}$ & 1.809 .700 .000 & 7.145 .640 & 0,39 \\
\hline $\mathbf{2 0 1 4}$ & 2.044 .500 .000 & 10.816 .515 & 0,53 \\
\hline $\mathbf{2 0 1 5}$ & 2.338 .600 .000 & 683.179 & 0,03 \\
\hline $\mathbf{2 0 1 6}$ & 2.608 .500 .000 & 27.716 .518 & 1,06 \\
\hline $\mathbf{2 0 1 7}$ & 3.106 .500 .000 & 56.168 .264 & 1,81 \\
\hline $\mathbf{2 0 1 8}$ & 3.740 .500 .000 & 101.139 .099 & 2,70 \\
\hline
\end{tabular}

Source: Cumhurbaşkanlığı Strateji ve Bütçe Başkanlığı, Gösterge ve İstatistikler (2018-2019); Hazine ve Maliye Bakanlığı (2019), Temel Ekonomik Büyüklükler (2009-2019), Ankara: Hazine ve Maliye Bakanlı̆̆ı, Bütçe Mali Kontrol Genel Müdürlüğü, 2019.

Indeed, the highest rate of PSBR as the financial crisis year in 2009, and then it is also seen that the proportional increase in the real value of PSBR in 2018 has been remarkable increasing due to the current account deficit in Turkey. In graph 1 below, it is possible to see more clearly these structural real change values and fluctuations in the process. But, that is a second reason the represents a more important approach for our study together with the other macro various. This process, in which the external balance of payments deficits and tax revenues experienced significant deviations, also caused significant fluctuations in terms of financial balances, in which PSBR was also directly affected (Özen et al., 2013).

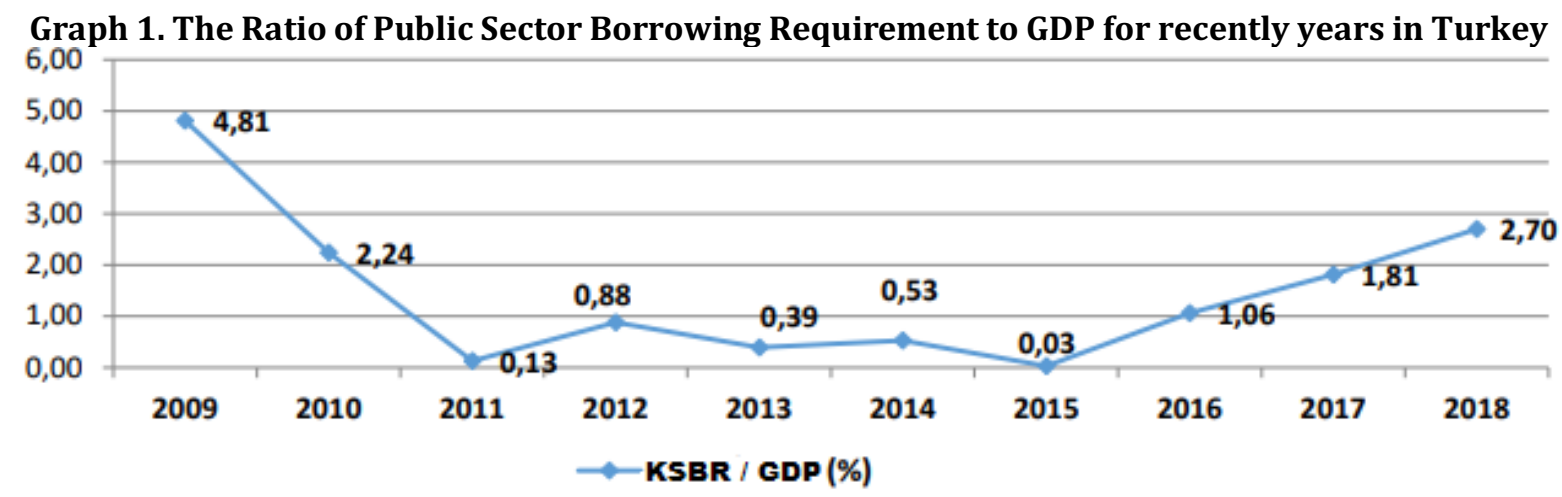

Source: Hazine ve Maliye Bakanlığı (2019), Temel Ekonomik Büyüklükler (2009-2019), Ankara: Hazine ve Maliye Bakanlığı, Bütçe Mali Kontrol Genel Müdürlüğü, 2019.

As seen on the graph 1, as a ratio of PSBR to GDP the periodical alterations mean not the fiscal stability after 2009. In terms of the reasons for this variability, two important comments can be made. The first of these is that PSBR has been in a continuous fluctuating course and its hypersensitivity to the process. In the post-2009 period, PSBR has been affected by the financial vulnerability process (Özen et al., 2013). This interaction is also a period in which corporate stability expectations continue. On the other hand, in fact that is this process has been referring to the process in which other negative external problems come to the fore in terms of PSBR (Republic of Turkey Ministry of Treasury and Finance, 2019). 


\section{ECONOMETRIC METHOD, DATA SET AND EMPIRICAL FINDINGS}

In our study, macro variables from 1983 to 2019 have been based on a time series model. In other words, and our data set is based on macro bases based on annual variables. In our econometric approach, the dependent variable is Public Sector Borrowing Requirement (PSBR). As other independent variables, Export Increase Rates, Investment Rates to Export, Industrial Production Index Proportional Changes, Consumption Goods and Changes in Investment Goods were taken as basis. Independent variable values, which are treated as a time series by years, have been adjusted for seasonal variance variations, and then the result variable related to PSBR is the result variable between 1983-2019 years which is not affected by variance variations. Time series covering the years 1983-2019 for all independent variables in our model variables, within the official data of the Central Bank of the Republic of Turkey (CBRT) and Turkey Statistical Institute (TSI) was created based. We can express our mentioned theoretical model as follows:

$$
Y=\beta_{1}+\beta_{2} X_{2}+\beta_{3} X_{3}+\beta_{4} X_{4}+
$$

Our econometric model is a one-way simultaneity model and is related to determinations by Least Squares Method (LSM), within the scope of cause-effect relationship. It is assumed that there is no two-way causality relationship between the variables, and so the model has been formulated as a single. As seen in Equation 1, " $\beta$ " value is our constant coefficient value in the model and creates an impact value on each independent variable in the model. It is possible to see the semantic responses of the dependent and independent variables in the econometric time series model in the table below:

Table 2. The Mutual Meaning Expression of Concepts in the Model

\begin{tabular}{|l|l|}
\hline BOR__GER__ & Public Sector Borrowing Requirement \\
\hline T_YTRZ_D_P_ & Investment Demand Variability for Foreign Market \\
\hline TP_SAN_URT_END___- & Total Industrial Production Index Variability \\
\hline YATIRIM_MALLARI & Investment Goods Demand Variability \\
\hline
\end{tabular}

When we establish our model within the framework of equality 1 , which expresses the time series model, we can make the placement of these expressions of meaning within the scope of our model as follows:

\section{LS DIFBOR__GER_MUT DIFTOP_VER DIFT_YTRZ_D_P_DIFTP_SAN_URT_END DIFYATIRIM_MALLARI C

\section{Estimation Equation: \\ DIFBOR_GER_MUT $=\mathrm{C}(1) *$ DIFTOP_VER + C(2)*DIFT_YTRZ_D_P_+ $\mathrm{C}(3) *$ DIFTP_SAN_URT_END___ + C(4)*DIFYATIRIM_MALLARI + C(5)}

Our "Dependent Variable" value, as it can be understood from our study, is the expression value in "BOR_GER_MUT" characterizing the expression Public Sector Borrowing Requirement. In our model, firstly it is aimed to test the effect of tax revenues on the Public Sector Borrowing Requirement.

In addition, it was aimed to question a possible borrowing requirement by including industrial production, which has a significant share in the increase of national tax revenues, and proportional increases in investments in foreign markets. Questioning the negative effect of all these independent variables on investment rates also aimed at providing an up-to-date approach to the model. In determining the right model, deterministic properties were tested and the series was aimed to be purged for seasonal effects, and the aim was to establish a model with 
fixed trend target. In this concerned analytical framework, it is assumed that there has been no dummy variable in our model.

\section{Testing Model}

In testing the model, all variables were first subjected to stationary testing and the sequences were ensured to be stationary. Here, firstly, the aim is to clear the non-stationary array from the error terms. For this purpose, the first difference $(-1)$ of the sequences was taken first, and then the second differences $(-2)$ were taken to ensure absolute equality of probability (prob.) values to zero. Augmented Dickey-Fuller Test (ADF) was preferred as the method of performing unit root test in ensuring stationarity and other non-stop elements were rejected within the framework of "H = 0" thesis. In unit root test analysis of the model, we use "Extended DickeyFuller Unit Root Test (Augmented Dickey-Fuller Test; ADF)". In unit root test analysis of the model, we use "Extended Dickey-Fuller Unit Root Test (Augmented Dickey-Fuller Test; ADF)" within its theoretical below (Aritova and Federova, 2016). Augmented Dickey-Fuller Test; (ADF):

$$
\begin{aligned}
& \Delta Y_{t}=\beta_{1}+\beta_{2} t+\delta Y_{(t-1)}+\alpha_{i}+u_{\mathrm{t}} \\
& \Delta X_{t}=\alpha_{0}+\beta t+\rho X_{t-1}+\sum_{i=1}^{k} \beta_{i} \Delta X_{t-i}+\varepsilon_{t}
\end{aligned}
$$

$$
\begin{aligned}
\mathrm{H}_{0}: \sigma_{\mathrm{u}}^{2} & =0 \\
\mathrm{H}_{1}: \sigma_{\mathrm{u}^{2}} & \neq 0
\end{aligned}
$$

The fixed and non-fixed terms of the model in question and the theoretical background with trendless and trend of the model are given below:

$$
\begin{aligned}
& \text { (Unfixed and } \\
& \text { Trendless Model) }
\end{aligned}
$$

(Fixed and Trendless Model)

(Fixed and Trend Model)

$$
\Delta Y_{t}=\delta Y_{t-1}+\sum_{j=2}^{k} \delta_{j} \Delta Y_{t-j+1}+e_{t}
$$$$
\Delta Y_{t}=\alpha+\delta Y_{t-1}+\sum_{j=2}^{k} \delta_{j} \Delta Y_{t-j+1}+e_{t}
$$

$$
\Delta Y_{t}=\alpha+\beta t+\delta Y_{t-1}+\sum_{j=2}^{k} \delta_{j} \Delta Y_{t-j+1}+e_{t}
$$

Our econometric model, which we have established, has been tested with and without trend, as well as fixed and non-fixed values, and it has been observed that the unit root results are the same within the framework of Augmented Dickey-Fuller approach. The number of delays in the implementation of the unit root test has been determined by SC (Schwarz Info Criterion). Test statistics are also calculated as $\boldsymbol{\tau}=\boldsymbol{\delta} / \boldsymbol{S}_{\boldsymbol{\delta}}$. Since “ $\mathbf{H}_{0}: \boldsymbol{\sigma}_{\mathrm{u}}{ }^{2}=\mathbf{0}$ " equation is obtained in our findings, our model cannot be rejected. Unit root test results showing the stationary variable series of our model are as follows: 
Table 3. Unit Root Test results

\begin{tabular}{|l|l|l|l|l|}
\hline Variable & Coefficient & Std. Error & t-Statistic & Prob. \\
\hline D(DIFBOR_GER_MUT(-2) & -3.521286 & 0.508510 & -6.924709 & 0.0000 \\
\hline D(DIFTOP_VER(-2) & & & & \\
\hline D(DIFT_YTRZ_D_P_(-2) & -1.321253 & 0.168167 & -7.856777 & 0.0000 \\
\hline D(TP_SAN_URT_END_(-2) & -1.547694 & 0.142126 & -10.88961 & 0.0000 \\
\hline D(DIFYATIRIM_MALLARI(-2) & -2.664469 & 0.209624 & -12.71070 & 0.0000 \\
\hline
\end{tabular}

As can be seen in Table 3, probability values (prob.) Of all variable values are zero. This is an important indicator in ensuring the stagnation in the series. In addition, "t-statistics" values are above the variance distribution deviation values. Stability of all variables of our model has been ensured and data series have been decontaminated and purged from seasonal deviation values. On the other hand, Residual, Actual and Fitted positions related to the distribution of unit root test values are also important to toward express the stability of the series. It is possible to monitor the structural graph value distribution of the station root test values of the data in our model in the following graph 2:

Graph 2. The Appearance of Residual, Actual and Fitted Graph

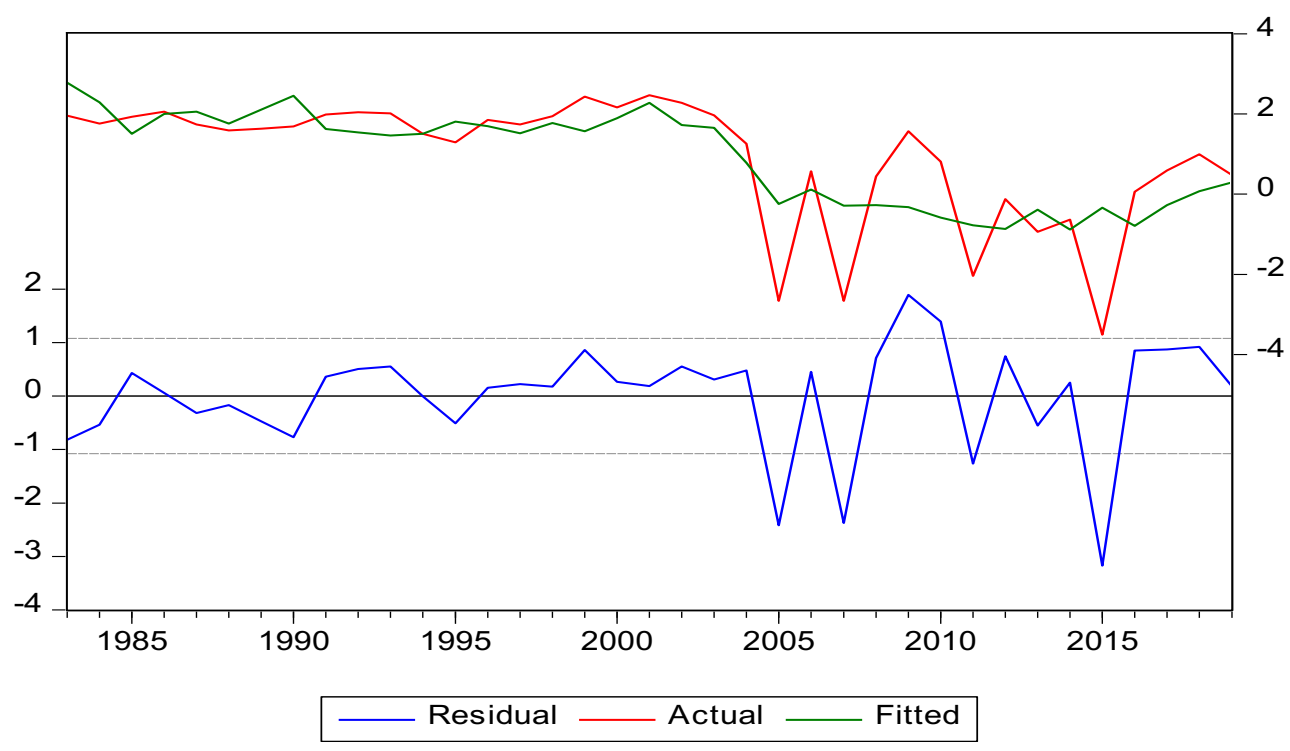

As can be seen in Graph 2, the distribution of Residual values has been understood to remain stable. Because, seasonal effects purified between 1985 and 2019 have created an important stable values period in this regard. The stasis in the Actual approach of the series, on the other hand, has experienced a structural fragility after 2004.

The reason for this is the increase in the real value of the Public Sector Borrowing Requirement after 2004. However, the assumption that there was no inflationist-based dummy variable in the stationary series gave healthy results in the Actual stationary distribution of the model, and so the dummy variable values have been not included in our model. It has been also seen that Fitted stationary values have been in harmony with Actual stationary values as median series values. 
In addition, it has been also aimed to test the "Correlogram Distribution" of these data series in order to give meaningful and accurate results of the time series values in our model. Below, it is observed that the distribution of our model continues between these two dashed lines.

Table 4. Correlogram of Residuals Squared

Date: $03 / 02 / 20$ Time: $11: 16$

Sample: 19832019

Included observations: 37

\begin{tabular}{|c|c|c|c|c|c|c|}
\hline Autocorrelation & Partial Correlation & & $\mathrm{AC}$ & PAC & Q-Stat & Prob \\
\hline .1 .1 & .1 .1 & 1 & -0.056 & -0.056 & 0.1239 & 0.725 \\
\hline$.\left.\right|^{* *} \mid$ & $.\left.\right|^{* *} \mid$ & 2 & 0.238 & 0.236 & 2.4632 & 0.292 \\
\hline .1 .1 & .1 .1 & 3 & -0.010 & 0.014 & 2.4673 & 0.481 \\
\hline$.\left.\right|^{*} \cdot \mid$ & .1 .1 & 4 & 0.081 & 0.027 & 2.7541 & 0.600 \\
\hline .1 .1 & $.1^{*} . \mid$ & 5 & 0.073 & 0.082 & 2.9962 & 0.701 \\
\hline $.1^{*} . \quad \mid$ & $.1^{*} . \quad \mid$ & 6 & 0.175 & 0.168 & 4.4177 & 0.620 \\
\hline$\cdot{ }^{*} \mid . \quad 1$ & 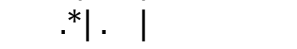 & 7 & -0.084 & -0.112 & 4.7557 & 0.690 \\
\hline$.\left.\right|^{* *} \mid$ & $.1^{*} . \quad \mid$ & 8 & 0.256 & 0.188 & 8.0046 & 0.433 \\
\hline$*||$. & .1 .1 & 9 & -0.110 & -0.064 & 8.6317 & 0.472 \\
\hline$.\left.\right|^{* *} \mid$ & $.\left.\right|^{*} . \quad \mid$ & 10 & 0.268 & 0.172 & 12.460 & 0.255 \\
\hline$\cdot *|\cdot|$ & .1 .1 & 11 & -0.075 & -0.060 & 12.775 & 0.308 \\
\hline$\cdot * i . j$ & $* *||$. & 12 & -0.095 & -0.233 & 13.300 & 0.348 \\
\hline.$* 1.1$ & .1 .1 & 13 & -0.066 & -0.062 & 13.559 & 0.406 \\
\hline$*^{* 1} .1$ & $*||$. & 14 & -0.107 & -0.142 & 14.282 & 0.429 \\
\hline .1 .1 & .1 .1 & 15 & -0.063 & -0.033 & 14.544 & 0.485 \\
\hline .1 .1 & $*^{*} .1$ & 16 & -0.035 & -0.120 & 14.627 & 0.552 \\
\hline
\end{tabular}

This is because the Correlogram Distribution shows the series of the model more clearly the meaningful distribution of the distribution. Two-sided dashed lines in the Chorelogram distribution show the 95 percent confidence interval. In case the time series for determining the normal distribution values developed by Bartlett are "White Noise", the sample autocorrelation value has a "1 / T (number of observations)" variance and zero mean for thenormal distribution.

As observed in Table 2, our observation number is $\mathrm{T}=37.0 .168$ and $1.96(0.168)=0.322$ value is meaningful. Because every autocorrelation value obtained has a place in the range of \pm 0.322 , and the hypothesis that the model's " $\boldsymbol{\rho}_{\mathbf{k}}$ " values are zero cannot be rejected. In other words, the fact that $\mathrm{AC}$ and PAC values are in the range of \pm 0.168 is meaningful in terms of expressing the stability of the series. It is possible to see the structural graphic distribution of this stationarity as Recursive Residual below: 
Graph 3. The Appearance of Recursive Residual

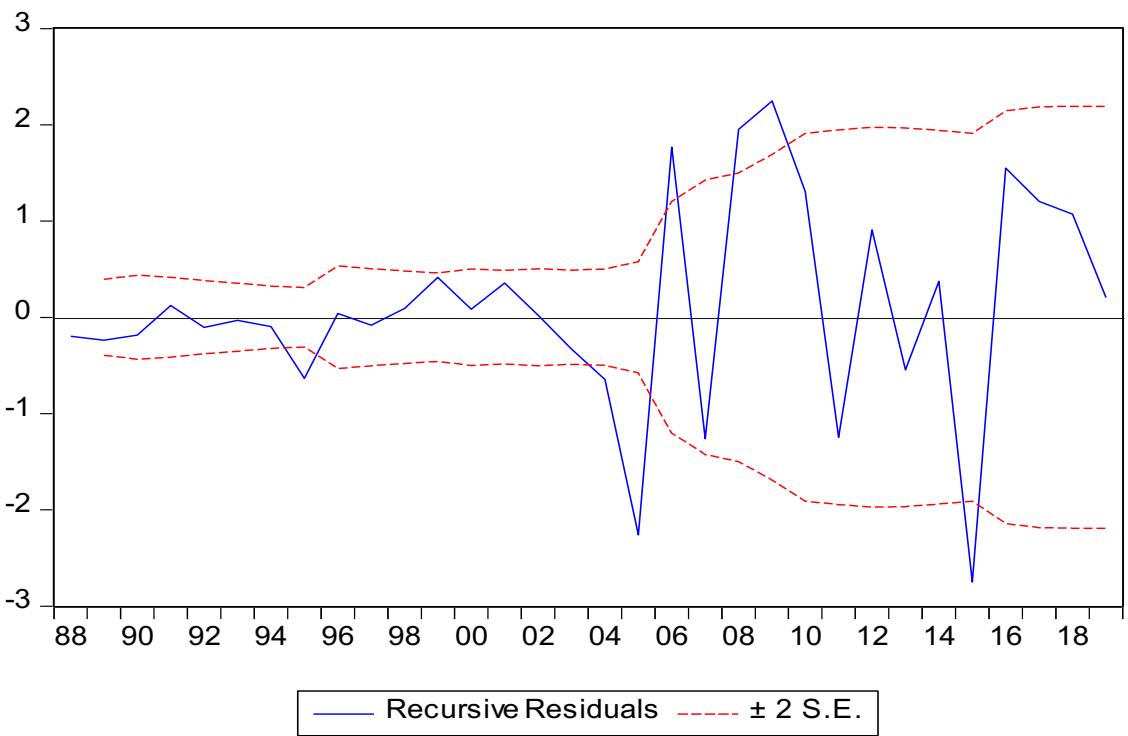

The Appearance of Recursive Residual distribution shown in Graph 3 shows an important symmetrical distribution in testing the accuracy of our model. The Recursive Residual distribution between broken lines is a meaningful distribution that shows that our model gives correct results. The stationarity distribution for the root test between 1983-2019 is significant and handy for model and the data series as shown in Graph 3 toward to use all the data series.

\section{Testing the Accuracy of the Model}

In testing our model, we prefer "Ramsey Reset Test application. In this context, we found Least R-squared values again within the framework of the Ramsey Reset test of the model we created and we determined the F-statistic probability value by comparing these values with the previous values. Comparison with the significance value reveals the meaningful interpretation of our model. In the table below, it is possible to monitor the distribution of the Ramsey Reset Test Summary Values, which also show the probability values:

Table 5. The Ramsey Reset Test Summary Values

\begin{tabular}{llll}
\hline & Value & df & Probability \\
\hline F-statistic & 4.263209 & $(2,30)$ & 0.0235 \\
Likelihood ratio & 9.255432 & 2 & 0.0098 \\
R-squared & 0.659006 & Mean dependent var & 0.924569 \\
Adjusted R-squared & 0.590807 & S.D. dependent var & 1.536770
\end{tabular}

The probability value for the F-statistic determined as shown in Table 5 was determined as "0.0235". The Ramsey Formulation below was used for the Ramsey significance test in determining this value. This value calculation is as follows:

$$
F=\frac{\left(R_{\text {New }}^{2}-R_{\text {Old }}^{2}\right) / v}{\left(1-R_{\text {New }}^{2}\right) / n-k} \sim F_{(v, n-k)}
$$

$\mathrm{F}=[(0.659006-0.562091) / 4] /[(1-0.659006) / 37-6]=0.0235$.

The value of 0.0235 found is below the probability value of 0.05 . Namely, $0.05>0.0235$. This position of the probability value reveals the meaningful significance of the model. On the other hand, "Likelihood Ratio" value has also strengthened the meaningfully of model the significance by being below 0.05 . Afterwards, the accuracy of the model was discussed on the basis of the independent variables that make up the model, and its accuracy meaningfully were questioned 
results in the Public Sector Borrowing Requirement by approximately "1.7576 \%" a positive effect. This positive result means "1.7576\%" shrinkage proportionally in the Public Sector Borrowing Requirement (PSBR). In this context, the positive effect of the increase in tax revenues in public deficits is meaningful as shrinkage in public cash deficit.

On the other hand, it is seen that the increases in the industrial production index (DIFTP_SAN_URT_END) have a positive effect on the Public Sector Borrowing Requirement. This effect is due to the export-oriented structure of the increases in industrial production and its positive effect on the National Income. However, this positive effect cannot be said to have an important place on the public debt structure. In our findings, this value has only ensured a decrease of about $0.05 \%$ on the Public Sector Borrowing Requirement despite a one-unit increase in value.

However, it is necessary to also mention two independent variables that have a negative impact on the PSBR. The most important of these variables is the negative impact of total investment expenditures (DIFYATIRIM_MALLARI). Indeed, "one unit" proportional increase in investment expenditures between 1983-2019 negatively affects the PBSR by "-2.1319\%". It should be emphasized that this change in total public investment expenditures has nearly twice the deficit effect on PSBR. Indeed, as the position of this determination related to PSBR in line with public debt increases more in the same years supports this argument. This finding shows that increasing investment expenditures are financed by public borrowings.

Therefore, the negative impact of increased public borrowings on the PBSR has caused the PBSR to grow proportionally. However, another independent variable that has a negative impact on PSBR appears in investment rates (DIFT_YTRZ_D_P) for foreign markets. Although it has a small proportion within the scope of all investments, its impact level is significant to the extent that it cannot be rejected. In this context, it is observed that the investments in foreign markets have been adversely affected by PSBR proportionally, about \% -0.2106 for the increase of one unit per cent. Namely, it is observed that investments in foreign market investments (DIFT_YTRZ_D_P) have a negative effect of "-0.2106" as a ratio. This negativity shows that PSBR has grown more and it mean a more comprehensive debt burden. In other words, each unit (one unit) investment in foreign markets (DIFT_YTRZ_D_P) causes public debt to increase by 0.2106 . It can be said that the most important reason for this situation is that the investments for foreign markets for export reveal a different financing portfolio. In addition, the limit effect values of the independent variables in our model regarding the unit value effects on the PSBR are also significant in terms of expressing the results of our model. The distribution of limit effect values can be seen in Table 8 below.

Table 8. The Coefficient Covariance Matrix Disintegration

\begin{tabular}{|c|c|c|c|c|}
\hline & DIFTOP_VER & DIFT_YTRZ_D_P & $\begin{array}{l}\text { DIFTP_SAN_ } \\
\text { URT_END_ }\end{array}$ & $\begin{array}{l}\text { DIFYATIRIM } \\
\text { _MALLARI }\end{array}$ \\
\hline DIFTOP_VER & 3.591620888 & -0.066230383 & 0.019410372 & -1.163421266 \\
\hline DIFT_YTRZ_D_P & -0.066230383 & 0.004729595 & -0.000745994 & 0.151616149 \\
\hline $\begin{array}{l}\text { DIFTP_SAN_URT_ } \\
\text { END___- }\end{array}$ & 0.019410372 & 0.000745994 & 0.000741226 & -0.047776083 \\
\hline $\begin{array}{l}\text { DIFYATIRIM_MAI } \\
\text { LARI }\end{array}$ & -1.163421266 & 0.151616149 & -0.047776083 & 7.571840779 \\
\hline
\end{tabular}

When we look at the distribution of covariance impact values, as shown in Table 8 , it is understood that the limit effect of the total tax revenues can create a proportional effect level of $3.5916 \%$ up to approximately twice the effect value in our findings. The negative impact of total tax revenues on investments in foreign markets as well as total investments can be clearly seen. However, its positive effect on the industrial production index is extremely low. It is understood 
that the highest positive proportional effect of investment goods on PSBR without a borrowing practice is approximately $7.518 \%$. There are two most important reasons for this situation. The first one is that all the investments made do not have a debt effect that may cause public deficits; The second is the increase in public financing provided in public income limits as a result of the expansionary tax effect on Value Added and tax base arising from investments.

\section{CONCLUSION}

In the model we put forward, the effect criteria of "The Total Tax Revenues", "Investments in Foreign Markets", Industrial Production Index and "Total Investments" of the four main independent variables affecting the PSBR phenomenon, of 1983-2019 have been questioned. It is understood that factors such as total tax revenues and investment expenditure have different regressive effects on the Public Sector Borrowing Requirement (PSBR). The proportional value change of PSBR values reveals a positive relationship with the public financial income that meets the cash needs, in addition to the different independent effects. Just need public financing in terms of each developing country like Turkey is an important phenomenon and an important indicator.

Turkey in 1983 - 2019 the real positive change in the ratio between the PSBR have been also monitored revealed a structure compatible with this approach in the financial literature. The findings of our model are meaningful and compatible with Turkey's economic and financial trends. In other words, the change is seen as a major positive impact of the tax revenues eon particularly about as $1.8 \%$ on PSBR. This variable height values of the impact tax revenues on developing countries of Turkey as a tax revenue which reveals its dependence on the high rate of growth. Public borrowing values explain the process of Turkey demonstrating needing the higher tax increase as a country that has confirmed our approach. However, a positive impact level can be mentioned regarding the increases in industrial production index, albeit proportionally small. The positive change effect of industrial production along 1983-2019 can be explained by export oriented industrial production products. In addition, the positive effect of sectoral growth that broadens the tax base cannot be neglected as a source of public finance. Undoubtedly, it is necessary to emphasize the negative effects of both independent variables, which are the subject of negative effects on PSBR in our model. It is observed that PSBR real values are negatively affected on the basis of "Total Investments" and "Investments to Foreign Markets". It is understood that these two independent variables, and especially the increases related to "Total Investments", constitute a borrowing requirement of approximately twice. As a result of inadequate savings along the 1983-2019 year for investments in Turkey, the case as a higher Borrowings, it possible to be explained as a result of the requirement increase of national savings. When these two facts based on the investments are considered as an impact level, it can be said that the effect on PSBR creates a very high unit coefficient effect. All this findings and determinations are put forth that Turkey needs a more positive financial sources impact as related to the evaluation of the PSBR, and but the conditional borrowings have to be not negative effect on investments. From another point of view, this structural phenomenon has required borrowings to be handled in a process far from being a source of financial investment. This process has revealed that more balanced public financial resources are needed especially in the years 1983-2019, when the current account deficits are quite high, and in addition to widening the tax base and it also requires sectoral outsourced investments in order for PSBR to enter a more positive process. 


\section{REFERENCES}

Alani, E. M.A.A. (2006), Crowding-Out and Crowding-In Effects Of Government Bonds Market on Private Sector Investment (Japanese Case Study), Chiba: Institute of Developing Economies (JETRO), 2006.

Aras, O.N. and Öztürk, M. (2011), "Constitutional Economics, Fiscal Policy Rules, and The Case of Turkey”, International Journal of Social Sciences and Humanity Studies, 3(2), 399-410.

Arltová, M. and Fedorová, D. (2016), “Selection of Unit Root Test on the Basis of Length of the Time Series and Value of AR(1) Parameter", Statistika, 96(3), 47-64.

Arslan, E., Bora, A. and Atlı, A. G. (2019), “Türkiye'de Bütçe Açıklarının Gelişimi ve Finansman Yöntemleri”, Social Mentality and Researcher Thinkers Journal, 5(19), 884-898.

Bailey, S. J. (1995), Public Sector Economics, London: Palgrave-Macmillan Texts in Economics, 1995.

Bank for International Settlement (2003), Fiscal Issues and Central Banking in Emerging Economies, Bank for International Settlement (BIS) Papers, No. 20, Basel: Bank for International Settlement (BIS) Monetary and Economic Department, October 2003.

Blejer, M. I. and Cheasty, A. (1991), “The Measurement of Fiscal Deficits: Analytical and Methodological Issues”, Journal of Economic Literature, 29(4), 1644-1678.

Central Bank of The Republic of Turkey (2010), Financial Stability Report-May 2010, Vol.10, Ankara: Central Bank of The Republic of Turkey (CBRT), 2010.

Cumhurbaşkanlığı Strateji ve Bütçe Başkanlığı, Gösterge ve İstatistikler (2018-2019).

Dağ, M. and Tügen, K. (2018), “Türkiye'de Bütçe Açlklarinin Nedenleri ve Finansman Yöntemleri: Dönemsel Bir Değerlendirme”, MCBÜ Sosyal Bilimler Dergisi, 16(2), 217-239.

Ertuğrul, A. and Selçuk, F. (2002), “Turkish Economy: 1980-2001”, Inflation and Disinflation in Turkey, A. Kibritçioğlu, L. Rittenberg and F. Selçuk (Eds.), Burlington: Ashgate Publishing Limited, 2002.

Gürkaynak, R. S., Kantur, Z., Taş, M. A. and Yıldırım, S. (2015), Monetary Policy in Turkey after Central Bank Independence, CESifo Working Paper No. 5582, Munich: CESifo Center for Economics Studies \& Ifo Institute, 2015.

Hazine ve Maliye Bakanlığı (2019), Temel Ekonomik Büyüklükler (2009-2019), Ankara: Hazine ve Maliye Bakanlığl, Bütçe Mali Kontrol Genel Müdürlüğü, 2019.

Iyidogan, P. V. (2013), “The Twin Deficits Phenomenon in Turkey: An Empirical Investigation”, Journal of Business, Economics \& Finance, 2(3), 36-42.

Keho, Y. (2010), "Budget Deficits and Economic Growth: Causality Evidence and Policy Implications for WAEMU Countries”, European Journal of Economics, Finance and Administrative Sciences, 18, 100-105.

Nikoloski, A. and Nedanovski, P. 2017, "Influence of Budget Deficit on Economic Growth: The Case of The Republic of Macedonia", The Journal of Accounting and Finance, July 2017 Special Issue, 116-126.

OECD (2018), OECD Economic Surveys: Turkey, July 2018.

Özen, E., Şahin, C. and Ünalmıș, İ. (2013), "External Financial Stress and External Financing Vulnerability in Turkey: Some Policy Implications for Financial Stability”, Central Bank Review, 13, (Special Issue-March), 65-74.

Republic of Turkey Ministry of Treasury and Finance (2019), Public Debt Management Report-2019, Ankara: Republic of Turkey Ministry of Treasury and Finance Publishing, 2019.

The Central Bank of the Republic of Turkey (2002), 2001 Annual Report, submitted to The General Assembly of Shareholders on April 26, 2002, Annual Report Prepared by The Board of Directors Report of the Committee of Auditors Balance Sheet, Profit and Loss Statement, and The Budget of the Central Bank for The Seventieth Accounting Year, Ankara: 2002.

Ucal, M. and Alici, A. (2010), “Is Fiscal Policy Sustainable in Turkey?”, Emerging Markets Finance \& Trade / MayJune 2010, 46(1), 83-93.

Ünver, M. and Doğru, B. (2015), "The Determinants of Economic Fragility: Case of The Fragile Five Countries”, Akdeniz Ünivesitesi İ.̇̇.B.F. Dergisi, (31), 1-24.

Wigley, A. A., Çağatay, S. and Attar, M. A. (2019), "An Overview of Economic Growth Dynamics in Turkey”, in The Dynamics of Growth in Emerging Economies: The Case of Turkey, Arzu Akkoyunlu Wigley and Selim Çağatay (Eds.), London and New York: Routledge Inc., 2019. 
Özker, A. N. (2020). The Scale Effect of Investments and Tax Incomes intended to Public Sector Borrowing Requirement in Last Period: Turkish Case. Archives of Business Research, 8(3), 221-234.

World Bank (2013), Turkey Green Growth Policy Paper: Towards a Greener Economy, New York: The International Bank for Reconstruction and Development / The World Bank, 2013.

Yeldan, A. E. (1997), "Financial Liberalization and Fiscal Repression in Turkey: Policy Analysis in a CGE Model with Financial Markets", Journal of Policy Modelling, 19(1), 79-117. 